\title{
Midway to Understanding: Seventy Years of History?
}

\section{Robert M. Dienesch}

\begin{abstract}
Cet essai réévalue l'historiographie de la bataille de Midway et soutient que la compréhension actuelle de la bataille, élaborée dans les années 1950 sur les bases de l'histoire officielle de la marine nationale américaine, est restée fondamentalement statique et incomplète depuis cinquante ans. Avec la publication récente d'une étude fonctionnelle de la bataille du point de vue japonais, une perspective, à la fois nouvelle et plus complète a été réalisée. Il révèle un ensemble beaucoup plus complexe des forces qui ont mené à façonner la bataille. Il indique également plusieurs domaines de recherche potentielle qui non seulement élargiront l'étude fonctionnelle de Midway, mais potentiellement transformeront notre pensée sur la guerre du Pacifique, tout en produisant une meilleure compréhension des forces qui ont façonné cette guerre.
\end{abstract}

As the sun came up over Midway atoll on 4 June of this year, it marked the seventieth anniversary of one of the most important battles of the Second World War. As the sun made its appearance that morning in 1942 the Japanese Empire was at the pinnacle of its power. Since 7 December 1941 the Imperial Japanese Navy (IJN) had neutralized virtually every threat to its newly expanded Empire. There was one exception, the remnants of the United States Navy's (USN) Pacific Fleet. Despite receiving a significant blow at Pearl Harbor, the U.S. Pacific Fleet remained the only threat to Japanese ambitions that could not be ignored. The Doolittle Raid on 18 April 1942 and the U.S. naval defence of the Coral Sea from 4-8 May 1942, which knocked two Japanese carriers out of action, demonstrated clearly that the U.S. was still in the fight. As air operations began on the Kido Butai off Midway Island in June 1942, the leadership of the Japanese Combined Fleet was convinced that this attack would end the threat. ${ }^{1}$ By forcing the remnants of the Pacific Fleet, specifically its aircraft carriers and their escorts, into the open to defend Midway the IJN could finally destroy them. By 10:30 that morning, however, this objective was in shambles as three of the four Japanese carriers were burning. As the sun set on 4 June, with four of their six front line carriers lost, the Imperial Japanese Navy had suffered its first major defeat. To make matters

1 The term Kido Butai can be translated several ways as meaning Mobile Task Force or Strike Force. It was the Combined Fleet's designation for its main carrier strike force together with escorting forces. See: Mark R. Peattie, Sunburst: The Rise of Japanese Naval Air Power, 1909-1941, (Annapolis, MD: Naval Institute Press, 2001),152; David C. Evans and Mark R. Peattie, Kaigun: Strategy, Tactics, and Technology in the Imperial Japanese Navy 1887-1941 (Annapolis, MD: Naval Institute Press, 1997), 349.

The Northern Mariner/le marin du nord, XXIII No. 1, (January 2013), 35-50 
worse for the Japanese these ships were assets that they could not afford to lose. While American naval strength continued to grow the Japanese were hard pressed to make good the losses of June 1942.

Midway, as one of the largest naval battles of the war, has garnered its fair share of historical scholarship. From books to articles to video documentaries and even a major Hollywood production, Midway is not just a central feature of the Pacific War, it has become part of American popular culture. Despite volumes being written about the battle, the account has remained generally unchanged since the $1950 \mathrm{~s}$. It focused on the defining moment when U.S. dive bombers swooped out of the sun to shatter the Japanese carriers, almost always portrayed as vulnerable because their decks were crowded with aircraft just bombing up to launch another long-range strike, a situation that resulted from failures of the Japanese leadership. This version of events has become the accepted wisdom about the battle. Yet, this view is not accurate.

As we hit the seventy year mark and as the number of veterans are getting fewer and memories are dimming, it is high time that historians re-examine the battle before our access to the living sources of memory are gone forever. It is not the author's intention to belittle or diminish the value of the work done to date. Rather the opposite: the goal of this article is to take existing scholarship as the starting point from which to emphasize the opportunity we now have to more thoroughly understand the Battle of Midway and by extension the Pacific War.

It is first necessary to try to place the history and the literature in perspective. The job of historians is essentially to create the collective memory of events and in our own way help to commemorate the past. As history, Midway has rightly taken on a central role in our understanding of the Pacific War. It is the quintessential decisive, almost Mahanian, engagement of the war and, with its dramatic twists and turns, the story captures the imagination. It seems to be a lopsided battle to say the least. The aggressive and dominant Imperial Japanese Navy, numerically superior to the USN in almost every aspect in 1942, threw their best trained and most experienced aircrews into the fray. Backed up by virtually the entire Japanese Navy in one of the most complex plans in history, Japanese carrier pilots were expected to annihilate the garrison forces and base facilities at Midway and any naval opposition they might encounter.

American carrier forces were outnumbered and in theory inferior in training and experience. They were also all that stood between the Japanese and total dominance in the Pacific. Having suffered humiliation at Pearl Harbor and having seen repeated Japanese victories during the early stages of the war, to say that American morale was in a precarious state is an understatement. The impression created by the standard version of events is that the U.S. rushed to counter the new thrust by the Japanese, throwing everything and anything it had at Midway in a desperate attempt to at least hold the line and stave off defeat. At Midway either the U.S. Navy would be victorious or the American west coast would be wide open to invasion.

The battle itself featured all the aspects of high drama. Aside from the tension and fear of any intensely fought military engagement, it is, in fact, an epic tale almost perfectly crafted for Hollywood. Mismatched forces and high stakes are only part of this 
drama. During the battle the initiative shifted several times between the antagonists and thus the story twists with surprises and sudden turns of events. The discovery of the Japanese fleet by the U.S. forces was electrifying for both sides. The Japanese air strikes at Midway were hard-fought actions in the face of a spirited and substantial American response, even though the defending U.S. fighter aircraft were completely outclassed by their technically superior opponents. Still, American bombers from Midway were already attacking the fleet, and the commander of the first Japanese strike reported that a second strike would be necessary to neutralize the bases on the islands. . Tension in the Japanese ships heightened with the shock of the discovery that the American fleet was present and the indecision that followed; then, from the agonizing weighing of alternatives, came the Japanese decision to re-arm the attack planes for anti-ship action and the resulting race to attack the American fleet before its air groups could strike. On both sides air crews were heroic, pressing home the attack in the face of extreme challenges. Notable are the obsolete U.S. torpedo bombers that charged in despite the lack of fighter escort, and persisted to the point of almost total annihilation. Their sacrifice is often portrayed as decisive for victory because of their role in drawing down both the Japanese combat air patrols and the eyes of the anti-aircraft gunners on the Japanese ships. This fatally weakened Japanese defences and allowed the dive bombers to strike virtually unopposed. During those dramatic moments, the five minutes that ended with three Japanese carriers afire, the course of the war changed. As the sun set, the U.S. and Japanese were on par for the first time in the war in terms of carrier strength. This balance then quickly shifted in favour of the Americans.

Exciting as this is, the chain of events is only part of the narrative. Midway is also a very human story. We tend to think of the individual commanders who played decisive roles such as Admirals Raymond Spruance, Jack Fletcher, Isoroku Yamamoto, and Chuichi Nagumo. These are men of obvious importance and have all drawn their fair share of the literature. But they are not the only figures that draw attention, and not the most interesting and enigmatic ones. Some of the participants of lesser rank are equally famous. Lieutenant George Gay, the only survivor of Torpedo 8 flying from the USS Hornet, who, after escaping from his torpedo plane, floated through the entire Japanese task force and observed events from a ringside seat. ${ }^{2}$ Behind the scenes people like Commander Joseph Rochefort, whose role in the events has now been acknowledged, played a central role in the battle. Responsible for the code breaking that revealed the Japanese plans, it was Rochefort who tricked the Japanese into revealing the objective of their attack through a false radio message intercepted by the Japanese whose response was tracked by the code breakers at Pearl Harbor. Portrayed in a folksy kind of way by actor Hal Holbrook in the 1976 big budget film Midway, Rochefort is as much an enigma now as he was then. ${ }^{3}$ Of course these are only the more famous individuals. The complete list of important characters is long and, sadly, many of the greatest sacrifices,

2 See George Gay, Sole Survivor: The Battle of Midway and Its Effect on His Life (Naples, FL.: Midway Publishers, 1979).

3 For a good source on Commander Rochefort, see: Elliot Carlson, Joe Rochefort's War: The Odyssey of the Codebreaker Who Outwitted Yamamoto at Midway (Annapolis, MD: Naval Institute Press, 2011). 
and the important moments in which they occurred, remain unknown.

Yet, despite the scale, confusion and the obvious significance of the battle, it is interesting to see that the historiography, the memory created by historians, was relatively stable until recently. Most of the orthodox account was established before the end of the 1950s. While the victors write the history, all early history is handicapped by its proximity to the events. The battle of Midway is no exception. The obvious place to begin is the official American account written by Samuel Eliot Morison. Volume four of his landmark history of the USN in the Second World War, Coral Sea, Midway and Submarine Actions, May 1942-August 1942 (1949) dealt specifically with Midway and built what became the standard chronology of events. Based on American records, interviews, and, likely, a few translated Japanese documents, it represents the first attempt at a scholarly study of the battle. Morison, however, labored under some serious limitations. Like most accounts done in the immediate aftermath of the war, access to classified information was far more limited than commonly known. Constrained by the requirements of secrecy as the U.S. was embarking on the Cold War, Morison by necessity found himself tied to interviews with as many surviving naval officers as possible and what official sources that were made available.

To augment American sources, it is most likely that Morison had access to one or two Japanese sources. This suggestion was made by authors Jonathan Parshall and Anthony Tully in their book Shattered Sword: The Untold Story of the Battle of Midway (2005). The two likeliest sources available in the late 1940s were Admiral Nagumo's after action log for the battle and the United States Strategic Bombing Survey (USSBS). ${ }^{4}$ Nagumo's report, captured on Saipan in 1944 and translated into English, was expected to present as accurate an account of events available at that time from the Japanese point of view. Further accounts provided by the USSBS interviews with surviving Japanese naval officers conducted immediately after the war rounded out a apparently clear and convincing understanding of the Japanese side of the battle. Yet there are several obvious problems with these sources. Both suffer from bias and limitations in terms of supporting documentation. In the case of the after action report, Nagumo offers no indication that it was based on a foundation of official documentation. The combination of Japanese government attempts to conceal its losses after the battle and the destruction of many records during the fire-bombing of Tokyo and other cities meant that it is highly improbable that Nagumo had access to documents to support his analysis. Further, it is impossible to verify what sources he used as he did not survive the war. Thus, the account can at best be considered his memoir of the event. The USSBS interviews suffer from similar limitations. Conducted after the war without access to the necessary documents to back up the results or to trigger memory, the interviews are essentially recollections collected years after the event. Human memory does shift with time especially when the memories concern complex and traumatic events. Furthermore, as the pool of interview candidates was limited to survivors of the war, the picture preserved was necessarily restricted, and certainly not comprehensive. There is also a strong

4 Jonathan Parshall and Anthony Tully, Shattered Sword: The Untold Story of the Battle of Midway (Washington, D.C.: Potomac Books, 2005; repr. 2007), xxii-xxiii. 
possibility of bias, as Nagumo and the officers interviewed would not unnaturally have tended to report events in a manner that put their own actions in as positive a light as possible, and particularly so in view of the lack of documentation to prompt and verify their accounts. Therefore, their accounts need to be handled carefully. ${ }^{5}$

Morison's account, despite its limitations, provides the general chronology and framework of the battle that is still used today. He began by setting the context for the events. Starting with both the Japanese and U.S. plans, Morison then proceeded to outline the order of battle for the operation for both sides. In the process, Morison emphasized the role of intelligence in preparing the U.S. reaction. The inclusion of the intelligence is interesting and raises the challenge of determining the workings of intelligence gathering, analysis and application to operations in this early period. While the battle could not have happened without the critical American advantage in knowledge of the enemy's intentions and forces, Morison's understanding of naval intelligence and its actual significance were quite far apart. Not given access to the code breaking materials, still highly classified, Morison's account of the role of intelligence amounted to little more than this statement: "Intelligence fed him [Nimitz] a fairly accurate account of Japanese plans and preparations, deduced from various bits of information from a variety of sources." With nothing else to go on, the implication is the intelligence gathered was important but beyond that remained a mystery. ${ }^{7}$

The remainder of Morison's account lays the battle out as it has been generally been accepted by most subsequent scholars. The Japanese initiated the battle with an air strike from all four carriers on Midway atoll. On all four carriers aircraft were held in reserve armed for a naval strike in case of an American surface force appearing in the area. While the strike on Midway was being delivered Japanese scout planes were to provide security for the operation. One of these scouts from the cruiser Tone was launched late, and the rest did not report any enemy naval forces in the area. Before the scouts all reported, repeated air strikes on the Japanese fleet from Midway and a request from the Midway strike commander Lieutenant Tomonaga combined to convince Nagumo at 7:15 am of the need for a second strike on the island. The reserve aircraft held ready and armed for an anti-shipping mission were ordered rearmed with land-attack bombs while the first strike returned from Midway. ${ }^{8}$ Less than fifteen minutes later, the Tone's scout reported enemy surface forces and Nagumo, indecisive due to the vague nature of the report, delayed a decision as to whether or not to stop the rearming of the reserve aircraft. With clarification about the enemy surface formation received just after 8 am, and a warning of an enemy carrier at 8:20 am, Nagumo was caught ill-prepared. With half his strike aircraft returning from the attack on Midway and the other half in the process of being rearmed for land operations, he had no means to strike the American

5 Ibid., xxii-xxiii.

6 Samuel Eliot Morison, The History of US Naval Operations in World War Two, Vol. IV: Coral Sea, Midway and Submarine Actions, May 1942-August 1942 (Boston: Little, Brown and Co., 1949, repr. 1961), 80.

7 Ibid., 69-100.

8 Ibid., 100-107. 
fleet. With repeated raids from Midway delaying his ability to rearm and counter attack, Nagumo was doomed. ${ }^{9}$

Morison skillfully portrayed the events that followed. While Nagumo was making his decisions, U.S. carrier aircraft were winging their way towards destiny. Most of Hornet's attack group missed the Japanese carriers, but the torpedo plane squadron began what was the last battle for four of the Japanese carriers that had launched the attack on Pearl Harbor. The torpedo bombers, without any fighter protection, were annihilated in a daring attack into the teeth of the Japanese fleet. Like the Enterprise and Yorktown torpedo bombers that followed in their wake, the Hornet's torpedo squadron suffered horrendous losses without scoring a single hit. Only six aircraft out of three squadrons returning to the carriers. These heavy casualties were seen by Morison as the key to victory, however: the torpedo bombers' tenacity delayed the Japanese attack against the American fleet. Defence against the American aircraft, including violent course changes by the Japanese carriers to avoid torpedoes, caused the loss of further precious time in both rearming aircraft and spotting them on deck for takeoff. Most standard accounts time the completion of preparations for takeoff on the Japanese carriers as shortly before the American dive bomber attack that followed the ill-fated strikes by the torpedo planes. The failed torpedo bomber attacks, moreover, had drawn down the Japanese combat air patrol to the low level of the torpedo strikes, stripping the carriers of airborne defenses at altitude just as the high-flying dive bombers found their targets. ${ }^{10}$ The dive bomber attack, the decisive moment when three Japanese carriers were heavily hit, was thus set up by the heroic sacrifice of American pilots. The attack by the Dauntless dive bombers was of course the pivotal event of the battle. Within approximately five minutes three of four carriers were burning and by the end of the day the entire Japanese carrier force was lost.

Morison's emphasis on the dramatic moments, Nagumo's fatally delayed decision to prepare an air strike on the U.S. fleet, and the U.S. torpedo plane attacks that paved the way for the dive bombers, provided the framework for many authors that followed. The salient features were reinforced by what may be the most important and problematic source to come out of Japan about the Midway battle, Mitsuo Fuchida and Masatake Okumiya's Midway: The Battle that Doomed Japan, The Japanese Navy's Story. First published in Japan in 1951, it was translated into English in 1955 and helped to cement the accepted version of history for the next half century. Strikingly biased and seriously flawed, Fuchida's Midway is full of misstatements that have tarnished most of the subsequent interpretations of the battle. According to Parshall and Tully, Fuchida's account seriously distorted the historical record because the pivotal events that shaped the battle are portrayed inaccurately. Some of these key issues such as the shape and nature of the Japanese search plan, the intelligence that Nagumo had at his disposal that morning, the nature and tempo of Japanese flight operations and even the impact of the

Ibid., 107-112.

10 Ibid., 113-121. For an interesting read on the experience of the torpedo squadrons see: Alvin Kernan, The Unknown Battle of Midway: The Destruction of the American Torpedo Squadrons (New Haven, CT: Yale University Press, 2005). 
American dive bomber attack on the carriers were distorted. For Parshall and Tully these errors were purposeful and aimed with a political motivation to shift the blame for the Japanese loss onto Nagumo. ${ }^{11}$

A salient example was the search plan used by the Japanese on the morning of the battle. The search pattern was executed by seven scout aircraft from the cruiser forces screening the carriers. The Japanese plan, besides dependence on excellent visibility conditions, had other significant flaws. The small number of aircraft deployed bore no relation to the large potential battle space. Each aircraft flew out approximately three hundred nautical miles before turning to port for a short sixty mile run after which they returned home. As each aircraft could at best see only about twenty five miles on either side of the flight path, the plan left uncovered large expanses of ocean in which the USN could operate without being detected. Thus the plan depended on luck even in the unlikely circumstance of excellent visibility. Still, Fuchida's criticism of the plan was unfair. He focused on the single-phase search pattern, arguing that Nagumo should have carried out a two-phase search using more aircraft to ensure that the entire area was covered adequately. The criticism is based entirely on hindsight, however, without regard to the circumstances at the time. Determined to preserve maximum striking power, Nagumo was unwilling to devote more resources or time to the search. The intelligence available gave no indication that substantial American forces were in the area or headed towards it, so there was no compelling reason to attempt more comprehensive coverage, costly as that would have been in precious resources and time. The Japanese, moreover, did not begin to use two-phased search plans until mid-1943. To criticize the commanders for not using a search doctrine not yet in place is unfair at best. The fact that Fuchida placed the blame directly on Nagumo is an important aspect of his effort to make the admiral the scape goat for failure. ${ }^{12}$ While western observers have accepted this analysis almost whole heartedly, in Japan the opposite is the case. Fuchida and Okumiya have been debunked for almost twenty years. Alas, the damage that they did to historical understanding in the West remains.

By the 1960s and 1970s the pivotal role of the battle in the course of the Pacific war became a central feature of historical discourse, much of which perpetuated many of the flaws of earlier works. Walter Lord's 1967 classic Incredible Victory and Gordon W. Prange's Miracle at Midway (1982) are important examples of these later writings. In both cases, they present the same chronology of events with nearly the same emphasis on the same events found in the writings of Fuchida or Morison. The main difference is that both Lord and Prange played up the impact of the battle on the war. Going beyond the fact that it was a major reversal of the Japanese fortunes, they characterized the outcome as the result of almost divine intervention on the side of the U.S. Incredible Victory strongly emphasized the idea that the Americans, with the odds so stacked against them in terms of men, material and experience, should have lost the battle. The very title of

11 Parshall and Tully, Shattered Sword, xxiii; see also: Jonathan Parshall, "Reflecting on Fuchida, or 'A Tale of Three Whoppers,"' Naval War College Review 63, no. 2 (Spring 2010): 127-38. 
Prange's book, published by two of his graduate students after his death, declared the American victory to be a "miracle." Prange's book played an additional role in the historical memory of the battle. It described and emphasized the significant impact of American code breaking. ${ }^{13}$ The code breakers at Pearl Harbor not only provided advance warning of the attack but managed to prove conclusively before the battle that the target was Midway, provided most of the Japanese order of battle, and the core elements of the attack plan. This advantage played a central role in the "miracle" and has been played up in the popular perception. It is interesting to note that the latest research has begun to shake the understanding of these events further. Elliot Carlson's recent biography of Joseph Rochefort clearly demonstrates that the accepted code breaking story is still somewhat incomplete. Rochefort and his code breakers failed to discover the presence of Yamamoto and the main battle fleet as part of the attack plan. This potentially disastrous gap in American knowledge luckily did not disrupt the USN's operations. ${ }^{14}$

Until this point the orthodox school, despite the difficulties noted, successfully presents four of the key elements of historical enquiry. Readers have a fairly good sense of who was involved with a better grasp of the key players and figures and a lesser understanding of others involved in the battle. We have a good sense of where the events happened, within limits. Records of Second World War naval battles are never exact in terms of geographic position due to inaccuracy of navigation in the era and, unlike land combat, returning to the scene of the battle produces very little of value. In most cases there is also a rather strong sense of time; a reasonably strong chronology of the events which has been presented relatively consistently. Like the uncertainty concerning the geographic position of events, the chronology is not absolute and historians are aware of difficulties, but generally the reader is left with a sense of the tempo and sequence of events to help grasp the overall experience. Most important, the orthodox school presents the reader with what has generally been accepted as what happened. These works provide a relatively detailed understanding of the chain of events that transpired that day. The story is often written more from an American perspective, however there have been notable attempts to include elements of the Japanese side of the events. Yet the same elements tend to be repeated over and over, such as the failure of Japanese scouting missions or Nagumo's indecision.

On the surface, the orthodox account describes the battle effectively, even if emphasizing the dramatic moments and celebrating the American victory. However,

13 See: Gordon W. Prange, Miracle at Midway (New York: Penguin Books Ltd., 1982); Walter Lord, Incredible Victory, New York: Harper \& Row, 1967); for more discussion on the role of code breaking and its influence see: Ronald Lewin, The American Magic: Codes, Cyphers and the Defeat of Japan (New York: Farrar Straus Giroux, 1982); John Prados, Combined Fleet Decoded: The Secret History of American Intelligence and the Japanese Navy in World War II (New York: Random House, 1995); Edwin T. Layton with Roger Pineau and John Costello, And I Was There (New York: William Morrow, 1985); W. Holmes, Double Edged Secrets: U.S. Naval Intelligence Operations in the Pacific During World War II (Annapolis, MD.: Naval Institute Press, 1979).

14 Carlson, Joe Rochefort's War, 342-345. 
who, what, when, and where do not provide a complete understanding of the experience. Why events happen or an understanding of the forces that shaped the who, what, when, and where matter a great deal. Understanding why, and grasping the context, requires the reader to understand events from a different perspective, particularly functional issues relating to carrier operations in 1942 and more specifically how they relate to the battlespace. Currently the U.S. Department of Defense defines the term battlespace as the "environment, factors, and conditions that must be understood to successfully apply combat power, protect the force, or complete the mission. This includes the air, land, sea, space, and the included enemy and friendly forces; facilities; weather; terrain; the electromagnetic spectrum; and the information environment within the operational areas and areas of interest." 15 An integral part of this concept are issues like logistics, command and control, communications and the doctrine and training of the forces involved. In the orthodox interpretation, aspects of this are mentioned but a comprehensive understanding is never provided.

It is only relatively recently that revisionist scholarship has begun to have an impact on the historiography of Midway by examining the forces that shaped the battlespace. In every case they have approached the creation of historical memory from a very different perspective, one that examines the Imperial Japanese Navy (IJN) and how it shaped events. This places a far greater emphasis on understanding IJN doctrine, technology and training/mind set and how these impacted the Pacific war. The starting point was David Evans and Mark Peattie's Kaigun: Strategy, Tactics and Technology in the Imperial Japanese Navy (1997) and Peattie's Sunburst: The Rise of Japanese Naval Aviation (2002). Both are groundbreaking studies of Japanese naval doctrine. Kaigun brought to the forefront the true nature and shape of Japanese naval doctrine at various levels from anti-submarine warfare to carrier operations. These were the first books to provide a comprehensive analysis of how doctrine and technology shaped Japanese operations. As significant as Kaigun is to our understanding of the Imperial Japanese Navy, it could not be all encompassing. Attempting as it did to treat doctrine in a wide number of areas it produced an excellent summary and overview but greater substance was needed. Peattie's subsequent Sunburst focused exclusively on the rise and development of Japanese naval air power. Described by Masahiro Yamamoto as a "landmark English language work on the history of the Japanese navy" Sunburst provided a fascinating look at naval aviation from the Japanese perspective and in the process forced the reader to re-examine the accepted notions held in the West. ${ }^{16}$ Since every ship and every navy operates within the envelope defined by training, technology, and doctrine, books like these fundamentally reshaped our understanding of the Japanese side of the war. In both books, the emphasis on understanding why the Japanese navy operated as it did filled in an absolutely vital aspect of our understanding of the Pacific War. ${ }^{17}$

15 The definition can be found at: http://www.dtic.mil/doctrine/doctrine/other/officers guide_2000.pdf (retrieved February 2013.)

16 Masahiro Yamamoto, Review of Sunburst: the Rise of Japanese Naval Air Power, 19091941, by Mark R. Peattie, Journal of Japanese Studies 29, no. 1 (Winter, 2003): 140-143. 
These studies directly supported perhaps the most important book in the reassessment of the battle of Midway, Jonathan Parshall and Anthony Tully's Shattered Sword: The Untold Story of the Battle of Midway (2005). Parshall and Tully develop the findings of Evans and Peattie with new Japanese sources with what amounts to a lifetime's dedication to understanding Midway from the Japanese perspective. Here for the first time was a dedicated attempt to overcome the limitations of fifty years of research. Its goal was to produce the first truly comprehensive understanding of the battle and in the process correct the errors of Fuchida and others. The result was a merging of a functional understanding of Japanese carrier design, doctrine and operations, and Japanese records of the battle long ignored, or lost to most authors, into the most comprehensive examination of Midway to date. In the past, with most authors being ignorant of Japanese ship design, operations or doctrine, the tendency was to fall back on a form of mirror imaging. Using the U.S. experience as normative, they extrapolated Japanese actions based on American procedures of the period. In essence, they argued that all carriers were the same and therefore all nations worked the same way. Using the USN as a model (and one often misunderstood by the writers) they made assessments based on this flawed and inadequate understanding. The key differences in Japanese doctrine from their opponents were significant, and these insights completely reshaped our understanding of events. ${ }^{18}$ The authors identified a series of myths and shattered them. They tackled everything from the idea that the Japanese had an overwhelming advantage at Midway to the "mistakes" of Nagumo, in each case breaking down the components of the myth and correcting each of them. Parshall and Tully even addressed such basic matters as the long accepted positions of ships and aircraft at critical junctures, and the impact of issues such as Japanese aircraft production, and the effect that had on the number of aircraft available on the eve of the fleet's departure for the Midway operation. The authors stood the accepted narrative of Midway on its head. ${ }^{19}$

Parshall and Tully's work is a significant departure from the orthodox writing on Midway for several reasons. Obviously, the inclusion of new Japanese sources supported a richer and far more complete assessment of the battle. More important, their writing demonstrates a significant shift in thinking away from more conventional top down histories to reflect a simple truth expressed over a century ago by noted naval historian Sir Julian Corbett in his famous book England in the Seven Years' War (1907). Corbett warned the reader that scholars tend to overly focus on the dramatic moment, the decisive battle, where fleets are engaged and a war can be won or lost. Yes, those moments do appear on occasion, however they tend to be "invariably so dazzling in their dramatic intensity as to dull our vision of what they really mean and how they were brought about.

18 Parshall and Tully, Shattered Sword, xxv-xxvi.

19 The account put forward by Parshall and Tully in Shattered Sword is large and complex but well worth understanding. It is, in many ways, the closest we have gotten to a true account of the battle of Midway. For similar works see Dallas Woodbury Isom, Midway Inquest: Why the Japanese Lost the Battle of Midway (Bloomington, Indiana: Indiana University Press, 2007); Craig L. Symonds, The Battle of Midway (New York: Oxford University Press, 2011). Symonds book is particularly interesting as he returns to the role of individuals in the battle and seeks to merge the new history with the history of the people involved. 
The imagination comes naturally to concentrate itself upon such supreme catastrophes and to forget that war is not made up of them." ${ }^{20}$ History, and by extension historians, tend to encourage this phenomenon. Scholars fixate on these dramatic battles because they are fascinating and command attention. We emphasize these events and by extension the people who featured in them, but this does not necessarily provide understanding.

A deeper understanding requires us to reflect on another statement that Corbett gave regarding naval studies. Corbett argued, "The great dramatic moments of naval strategy have to be worked for" and while strategically speaking that means interfering with enemy plans and forcing them to come out and fight, that is not the end of the story. ${ }^{21}$ Operationally, or functionally speaking, naval battles are a product of a great many forces that are often little understood by most readers or are expected by authors to be in the knowledge base of the audience. As military activities have become more complex, the number of forces that shape battles have escalated. In the case of Midway, these forces were what shaped how the military strength of Japan and the United States were used that fateful day.

In Parshall and Tully's book these forces are clearly explicated for the first time. Most western authors have made a great deal of the fact that the Japanese aircraft lacked armour and self-sealing fuel tanks and of course underscore how American aircraft benefited from such technologies. However, this reasoning demonstrated a deeper problem and the true gap in our understanding. The Japanese did not, in fact, adopt these protective technologies because of an offensive mindset that set the temper of aircraft design and pilot training. The logical conclusion is that the offensive mindset also shaped carrier operations. Every activity on board the carriers from arming (and re-arming) of aircraft, to the rate at which aircraft could be raised and lowered from the flight deck, and the basic nature of flight operations were shaped by a mindset that was quite distinct in important respects from that in the U.S. Navy. While there were some similarities between Japanese and American carrier operations and doctrine, it is unrealistic to assume they were the same in the two navies. It took approximately sixty years for western authors to realize that there were differences.

The emphasis on understanding Japanese carrier doctrine, aircraft and carrier design, organizational and training issues and how they impacted the timing and tempo of flight operations are all aspects of what is often called the functional approach to military history. To understand this approach, some examples warrant study. The obvious point to begin with is the question of the "miracle" of Midway. The perception is that the U.S. forces were outnumbered and under experienced going into the battle. Yet the Japanese fleet was far from the overwhelming force that is commonly believed. Of the six first line carriers in the Japanese fleet, two were unavailable due to damage and aircraft losses suffered at Coral Sea. The remaining four had been conducting almost continuous combat operations since early December 1941 all across the Pacific and into the Indian

20 Julian Corbett, England in the Seven Years' War, Vol. I, (London: Longmans, Green, and Co., 1907), 3.

21 Ibid., 4. 
Ocean. With barely a month to refit and rearm for Midway, the Japanese carrier forces were tired and in desperate need of retraining and re-equipping. Furthermore, all of Nagumo's carriers sailed with fewer aircraft than they should have due to slow industrial production. Despite having four carriers to the American three, the Japanese fleet only boasted about fifteen more aircraft than their antagonist. When the additional one hundred and twenty seven U.S. aircraft stationed at Midway are added, the miracle seems less miraculous. ${ }^{22}$

More generally, the assumption of most authors that the Japanese and American fleets operated their carriers in the same way is profoundly flawed. Each nation's doctrine reflected cultural and strategic values, technological limitations in weapon and ship design and of course a variety of other factors like the industrial capacities of the two nations. Only by understanding Japan and its military culture can the nature of Japanese naval doctrine be grasped. ${ }^{23}$

An example of the importance of doctrine is the Japanese search plan discussed above. Most authors were critical of the failure of the Japanese to adequately search for the American carriers, and gave great weight to this failure in explaining the Japanese losses. Parshall and Tully devoted considerable effort to examining not just the scale of the search plan but also the doctrine that shaped it. While Fuchida was critical of the plan, the fact remains that the Japanese search was well within what was expected for the period in terms of doctrine. Limited by the technology and range of aircraft and the need to maximize the strike against Midway, the search plan was well within standard practice. The authors went further to point out that a similar single stage search plan was the norm for the American fleet as well. Thus, the failure of the search aircraft that morning was a reflection of the doctrine, training and technology of the period that affected the performance of both navies. $^{24}$

Intimately related to the flawed scouting plan is the debate around Nagumo's decision to rearm the aircraft held back for an anti-ship mission in order to carry out the unplanned second attack on Midway and the ensuing crisis this created. Most historians identify this as the critical moment in the battle. The order to break the spot was given at 07:15 am, after most of the search planes had begun to return to the fleet and there was a clear expectation that no American ships were in the area. The rearming process based on the analysis of Japanese carrier operations provided by Parshall and Tully is clear. Approximately two and a half hours was needed to rearm the torpedo aircraft with bombs due to the need to change the attachment points on the planes as well as the munitions. When combined with the fact that the first strike of the day was returning and combat air patrols were continuously being launched and recovered it meant that more than two and a half hours were needed before a strike could be mounted. In the midst of the rearming, Tone's number four scout plane reported the U.S. fleet about 07:28 am with the message arriving on the bridge of Akagi, Nagumo's flag ship, before 07:45am. The timing is well 
established because Pearl Harbor code breakers monitored the transmission and the reply by Nagumo at 07:47 am. ${ }^{25}$

What is clear is that in the wake of this decision Nagumo was caught in a conundrum created by doctrine, technology and the practicalities of carrier operations. Following Japanese doctrine to launch torpedo planes, dive bombers and fighters together in a coordinated strike, he was bound to rearm his aircraft with an anti-shipping package. Caught by the time constraints of the rearming cycle and the need to recover his first strike of the day there was no practical way to launch a strike for hours. Japanese culture also worked against him. Confined to the exceedingly small bridge space on the Akagi, Nagumo was surrounded by his subordinates. In a culture that frowned upon publicly questioning a superior, Nagumo's staff could not approach him and make suggestions without publicly embarrassing their commanding officer. In a nation where that was socially and culturally forbidden, the very idea never crossed their minds. Unlike American admirals who had their own bridge with separate communications capabilities, who had the option of open discussion of issues, the Japanese were effectively hamstrung by the need to save face. Worse, the constant need to keep replacing the combat air patrol as the task force was under attack meant two things. First, the number of armed Zero fighters available to escort the strike was decreasing as Combat Air Patrol defence took precedent. Second, since the primary defence against air attack in the IJN was maneuver and not anti-aircraft fire from escorts, the rearming cycle was still slower than it otherwise would have been. The result was a serious delay in the ability to react to the American presence. Once the first strike of the day and the scout planes had launched, Nagumo was trapped by the reality of how the Japanese carriers functioned, the lack of aircraft and bad luck. What is clear was that he was not indecisive. He was caught by events beyond his ability to control. ${ }^{26}$

Not everyone is as accepting of Parshall and Tully's work. Ken Hansen, resident research fellow at the Centre for Foreign Policy Studies, Dalhousie University, and a retired commander in the Canadian Navy who was an instructor in the "operational art and campaign design at a joint war college," has been critical of Shattered Sword. ${ }^{27}$ Hansen's first major criticism concerned the treatment of command relationships between Admirals Nagumo, Yamamoto and Nagano at the Imperial Naval Headquarters. $\mathrm{He}$ found that Parshall and Tully were highly critical of Yamamoto, yet they failed to examine how the strategic decisions were made and by extension how this shaped the overall plan. Thus, for Hansen, the book focused on tactical matters, and did not properly address high level issues. ${ }^{28}$

25 Ibid., 149-161. Alternative theories include the fact that Nagumo received the message later, delaying the time when the rearming order was given. For an example of this see Isom, Midway Inquest, 104-123.

26 Parshall and Tully, Shattered Sword, 92-228.

27 Ken Hansen, Review of Shattered Sword: The Untold Story of the Battle of Midway, by Jonathan Parshall and Anthony Tully, The Northern Mariner/Le marin du nord XVI, no. 1 (2006), 95. 
His second, and related, main criticism is that the authors do not really understand naval principles of the operational art or of campaign design. From Hansen's perspective this led to problems in both the logic and analysis. ${ }^{29}$ While Hansen's criticism sounds credible on the surface it raises several important questions. Does the modern theory have a parallel in the Second World War, and if so how closely did it resemble the modern construct? How was it implemented and utilized by the Japanese at that time? Or is this a modern construct over laid on history? This makes the operational planning process a topic of potentially huge importance that is not often discussed.

While these criticisms should be noted, they do not discredit the text. Rather they indicate the strength and value of Shattered Sword while at the same time highlighting areas where continued research will benefit historian and reader alike. Hansen's criticisms point the reader to a glaring gap in our knowledge. While Shattered Sword is weak in this area, virtually every other major text seems to suffer from the same limitations. This signals a significant area for future research. However, due to the loss of Japanese records and the need to understand the culture as well as the language, it may prove to be very difficult to get at.

The issue of campaign design theory does raise the question of whether Hansen is using hindsight to criticize Parshall and Tully. As noted above, Parshall and Tully were rightly critical of Fuchida and Okumiya for their use of hindsight to shift blame for Midway to Nagumo. So caution is needed to avoid a similar trap. Underlying Hansen's criticism is another issue that is disturbing. Hansen placed a great deal of emphasis on the fact that Parshall was only a naval enthusiast as part of his argument that he did not understand naval strategy and concepts. The implication is that only a naval officer, with the suitable background and training, is really capable of understanding these ideas. This harkens back to the historiographical debate that an outsider can never understand the history of a particular group. In this case, only a military officer can really understand the Battle of Midway. This undercuts credibility of the criticism to say the least. ${ }^{30}$

While Hansen raises some legitimate criticisms, his greatest value to our understanding of the Battle of Midway transcends the issues he raised. As indicated above, the failure of scholars to rigorously examine the battle for decades produced a static interpretation of the events shaped by the victors and reinforced by a Japanese explanation that hoisted a scapegoat on history. Parshall and Tully's greatest value may not be whether they adequately understand campaign design theory but that they, with the help of Hansen, have re-opened a historical dialogue that has been missing for decades. This dialectic process will hopefully lead to more research not just on Midway but on the host of related issues discussed above. By incorporating more Japanese material into the discussion, and from a variety of sources, to provide a clearer insight into how the Kido Butai functioned Parshall and Tully grounded our understanding of the battle in the objective reality of Japanese naval doctrine and the functional limitations inherent in that doctrine. Within that context, the events of the battle, well known by many, take on a 
new and greater significance and thereby produce a more comprehensive understanding of what transpired on 4-7 June 1942.

The most disquieting aspect of their work is that it took over sixty years to achieve this more complete understanding. The only explanation for this failure to delve more deeply into the Battle of Midway has to rest squarely on two elements. First, with the clear U.S. victory, and the obvious key moments identified, scholars were complacent. This complacency was helped by the fact that Fuchida and Okumiya's interpretation of the Japanese side of the story seemed to mesh with the western interpretation and laid blame squarely on Nagumo. This conjunction of views neatly wrapped up the package of the battle of Midway for western scholars. That no western authors seem to have taken a critical eye toward Fuchida is astonishing especially in view of the fact that Japanese scholars have long dismissed the account. Second, Corbett's criticism of the fixation on battles also seems to be significant. Dramatic and inherently heroic, Midway was just ripe for myth making. With plenty of exciting and glorious moments to choose from, scholars were drawn there and away from explaining why those moments happened. When the scale of such a massive battle is added to the problem, it only intensifies the tendency to focus on key moments or aspects, ignoring the more fundamental influences that shaped it.

What is truly disturbing, however, is the fact that the story, despite the admirable work of many authors, is still incomplete. With a functional study of Japanese carrier doctrine, technology and training in hand, the absence of a study on the same scale of Shattered Sword on American operations clearly points to a significant gap in the literature. There is no cohesive account of U.S. carrier doctrine in 1942 let alone a study of how carrier and aircraft design shaped operations. Without this, our understanding of the Battle of Midway is incomplete. Directly related to this is the need by scholars to take the next logical step and link what we now know coming out of Midway to a greater understanding of the war in the Pacific. As Ken Hansen has indicated more work is needed on the higher command levels of the Imperial Japanese Navy and particularly how they planned operations. At the same time, how does the knowledge gained from Parshall and Tully reshape our understanding of the early stages of the war? How does it reshape our thinking on Pearl Harbor? What changes appeared after Midway that influenced the numerous engagements that followed? In Shattered Sword we have a remarkable window into the Japanese naval machine in June 1942. How can this be translated into a far better understanding of the Japanese side of the larger war? Better yet, can similar work on the American side be done to produce a more accurate and insightful history of World War Two in the Pacific? That is where scholars need to focus. The sad part of all this is that for sixty years, while the veterans aged and passed away, scholars squandered the opportunity to produce a balanced assessment of Midway. Complacency has denied a true understanding of events. Only through clear and focused effort can we overcome part of what we lost.

\section{Bibliography}

Carlson, Elliot. Joe Rochefort's War: The Odyssey of the Codebreaker Who Outwitted Yamamoto at Midway. Annapolis, MD: Naval Institute Press, 2011. 

Co., 1907.

Corbett, Julian. England in the Seven Years' War, Vol. I. London: Longmans, Green, and

Evans, David C., and Mark R. Peattie, Kaigun: Strategy, Tactics, and Technology in the Imperial Japanese Navy 1887-1941. Annapolis, MD: Naval Institute Press, 1997.

Gay, George. Sole Survivor: The Battle of Midway and Its Effect on His Life. Naples, FL: Midway Publishers, 1979.

Hansen, Ken. Review of Shattered Sword: The Untold Story of the Battle of Midway, by Jonathan Parshall and Anthony Tully. The Northern Mariner/Le marin du nord XVI, no. 1 (2006): 95-96.

Holmes, W. Double Edged Secrets: U.S. Naval Intelligence Operations in the Pacific During World War II. Annapolis, MD: Naval Institute Press, 1979.

Isom, Dallas Woodbury. Midway Inquest: Why the Japanese Lost the Battle of Midway. Bloomington, IN: Indiana University Press, 2007.

Kernan, Alvin. The Unknown Battle of Midway: The Destruction of the American Torpedo Squadrons. New Haven, CT: Yale University Press, 2005.

Layton, Edwin T. with Roger Pineau and John Costello. And I Was There. New York: William Morrow, 1985.

Lewin, Ronald. The American Magic: Codes, Cyphers and the Defeat of Japan. New York: Farrar Straus Giroux, 1982.

Lord, Walter. Incredible Victory. New York: Harper \& Row, 1967.

Morison, Samuel Eliot. The History of US Naval Operations in World War Two, Vol. IV: Coral Sea, Midway and Submarine Actions, May 1942-August 1942. 1949. Reprint, Boston: Little, Brown and Co., 1961.

Parshall, Jonathan. "Reflecting on Fuchida, or "A Tale of Three Whoppers." Naval War College Review 63, no. 2 (Spring 2010): 127-38. , and Anthony Tully, Shattered Sword: The Untold Story of the Battle of Midway. 2005. Reprint, Washington, DC: Potomac Books, 2007).

Peattie, Mark R. Sunburst: The Rise of Japanese Naval Air Power, 1909-1941. Annapolis, MD: Naval Institute Press, 2001.

Prados, John. Combined Fleet Decoded: The Secret History of American Intelligence and the Japanese Navy in World War II. New York: Random House, 1995.

Prange, Gordon W. Miracle at Midway. New York: Penguin Books Ltd., 1982.

Symonds, Craig L. The Battle of Midway. New York: Oxford University Press, 2011.

Yamamoto, Masahiro. Review of Sunburst: The Rise of Japanese Naval Air Power, 1909-1941, by Mark R. Peattie. Journal of Japanese Studies 29, no. 1 (Winter, 2003): 140-143.

The author would like to thank the numerous people who had a role in the creation of this article, especially those who took the time to not just listen but read aspects of the work. Robert Davison and Nic Clarke particularly stand out in this regard. As always, the views are mine and mine alone, as is the responsibility for any errors within the text. 